\title{
The development of telephone interviewing as a tool in marketing research - a survey of the literature
}

\author{
Hazel T. Suchard \\ Department of Business Economics, University of the Witwatersrand, Johannesburg
}

\begin{abstract}
This article is a historical overview of the development of telephone interviewing from the time of Gallup (1929) till today. Several advantages (such as costs, decreased risk and time, flexibility of research plan, etc.) and disadvantages (such as lack of visual interviewing aids, limitation of survey frame to subscribers) associated with telephone interviewing are described. Telephone sampling methods such as alphabetical lists and random digit dialing are discussed. Questionnaire design is emphasized and methods of developing the questionnaire and formulating questions are described. Computer control, voice pitch analysis, response latency, and non-contact and refusal rates are all discussed. Protection of privacy and maintenance of confidentiality are emphasized. The article concludes that professional telephone surveys are here to stay but are likely to face the obstacle of government regulation.
\end{abstract}

S. Afr. J. Bus. Mgmt. 1985, 16: $146-149$

Hierdie artikel is ' $n$ historiese oorsig van die ontwikkeling van telefoononderhoud vanaf die tyd van Gallup (1929) tot vandag. Verskeie voordele (soos koste, verminderde tydsverbruik en risiko, aanpasbaarheid van die navorsingsplan, ens.) sowel as nadele (soos die tekort aan visuele ondersteuningsmateriaal, en die tekort van 'n navorsingsraamwerk vir die verbruiker) word beskryf. Metodes om 'n verteenwoordigende steekproef te trek, soos alfabetiese lyste en ewekansige nommers, word bespreek. Die klem word veral op die ontwerp van bruikbare vraelyste gelê en metodes van vraelys-formulering en vraagformaat word voorgestel. Rekenaarbeheer, stemhoogte-analise, latente respons-patrone, nie-kontak en die voorkoms van wegwysing word ook verder uitgelig. Verder word etiese aspekte soos die beskerming van privaatheid en die behoud van vertroulikheid ook onderstreep. Hierdie oorsigsartikel wys daarop dat telefoonopnames waarskynlik blywend sal wees maar dat regulasies vanaf die regering waarskynlik toenemend beperkend sal inwerk op die gebruik van hierdie bemarkingsmedia.

S.-Afr. Tydskr. Bedryfsl. 1985, 16: 146-149

\section{A historical overview}

Telephone interviewing is the dominant method of survey research today with the greatest progress having taken place in the United States. The first type of telephone survey was a non-professional survey carried out without personal supervision and without monitoring, the interviewer using his own telephone.

It is possible to trace the use of these surveys back to 1929 when an American, Dr. George Gallup, conducted a telephone coincidental study of radio listening (Blankenship, 1977). As distinct from non-professional surveys, professional surveys, where telephoning is done at a central location, with a supervisor and with monitoring, can be traced back to 1959. It was in 1959 that Sindlinger and Company introduced monitored supervised central location interviewing (Blankenship, 1977). Professional surveys were later encouraged by the introduction of WATS (Wide Area Telecommunications Service) in the United States in 1961. By way of this system the bulk user of toll services purchases telephone time covering various areas of the United States at discount prices.

Today, the interviewer is assisted by on-line computers, in other words, a computer terminal is available to the interviewer and answers are punched into computer memory banks. CRT's (Cathode-Ray Tubes) are also used to show the questions being asked on a screen in front of the interviewer. In a typical survey questions asked depend on preceding questions. With computer programming questions are programmed according to preceding replies and there is no possibility of incorrect questions or inconsistent answers.

\section{Advantages and Disadvantages}

There are several advantages and disadvantages associated with telephone interviewing. The first advantage to consider is costs. Telephone surveys can reduce interview expenses appreciably. They have a cost advantage over personal interviews especially because locating a household takes less time on the telephone. When sample members are widely dispersed, a large amount of travel may be involved which creates escalating costs for personal interviewing. Economies of scale have been realized from the centralization of interviewing facilities and computer-based interviewing hardware is now economically feasible. The use of computers has decreased labour intensivity and telephone interviewing is thus less subject to cost increases arising from inflated wage rates. Mail surveys, however, have a cost advantage over telephone surveys.

Other advantages are that the interviewer is no longer at risk in a dangerous neighbourhood, has access to locked 
buildings, can overcome the problem of doormen rendering a respondent unavailable and has access to respondents during evening hours. There is also the time factor - telephone interviewing is fast and field operations can be completed speedily. Data can be coded, punched, verified, tabulated and analysed quickly. The research plan is made flexible as early results can lead to alteration or extension of the plan and sample. There is also a lack of interviewer bias as respondents are less likely to give socially desirable answers when interviewed on the telephone. Interviews on embarrassing or controversial subjects have been completed successfully, for example, Payne (1974), cited a successful telephone interview on the consumption of alcoholic beverages by women, with higher consumption levels being reported on the telephone than those reported in face-to-face interviews. Reactions to events can be obtained as they occur or immediately afterwards. A further advantage is that the influence of other family members or friends is eliminated. There is also an intimacy factor. People have been known to feel safer talking through an instrument that can be turned off at will than when conversing face-to-face. Monitoring can decrease interviewer bias and personal elements of the interviewer are eliminated, interviewer morale is increased as other interviewers share experiences and problems. There is no motivation to cheat as the interviewer is paid on a time basis. In a professional telephone survey the interviewer is observed and carefully supervised, it is possible to ensure that the correct respondent is being interviewed. Call-backs can be made quickly and cheaply.

As far as disadvantages are concerned, visual interviewing aids cannot be used in telephone interviewing and the interviewer cannot obtain observational data such as race, age, and socio-economic status. However, it is possible to overcome some of this. For example, it is possible to ascertain the income of respondents by using the correct questioning technique. There is also a limited length of time that respondents are willing to answer questions over the telephone. Rice (1979) queries this, however, and maintains that interviews of up to 60 minutes have been conducted successfully in certain countries, the important problem being whether the interview is interesting or not. Kildegaard (1966) has pointed out that maximum interview length depends on the nature of the universe and the topic of questioning. Also, questions that require looking up information cannot be asked. It is also still possible to transmit cues, which bias responses, over the telephone. Interviewers may convey attitudes by warmth or coldness, inflection, and tone of the voice. Sex and accent are also transmitted by voice and not very much in-depth probing can be used. Anonymity is not guaranteed and pictorial stimuli cannot be administered. (However, in the United States, videophones, cable television and two-way television are being investigated.) There may also be a greater proportion of no-answers in telephone surveys than in other survey methods. This has been attributed to the tendency of telephone interviewers to hurry when the respondent delays (Tigett, Barnes \& Bourgeois, 1975).

Another disadvantage is that the survey frame is limited to subscribers. In the United States the proportion of households with telephones is over $91 \%$ and it was argued, even in 1965, that current telephone coverage is at about the same level of completeness as many probability sample lists that often miss 5-10\% of all households (Kish, 1965). In other countries this is likely to be more of a problem. For example, in South Africa, $74 \%$ of white households have telephones and the percentage of black households having telephones is minimal, therefore this technique could not be used. In most countries there is a demographical resemblance among those who do not have telephones, as most of this group are farm and low-income, ghetto households. Another problem is that of households with unlisted telephone numbers. However, random digit dialing methods are now used to minimize or eliminate this bias.

It has been found that in some situations the combined use of telephone and face-to-face interviewing may be the optimal method. Telephone samples will be used for screening to locate special subgroups in the population, such as retired people, childless families, etc. and the final interview will be faceto-face.

\section{Telephone sampling methods}

The target population in telephone sampling is usually defined as all persons living in households with telephones. It is possible to use an alphabetical list for telephone sampling. However, there are problems. In some countries, individuals may be listed both by their business address and by their home address. In others, households may be listed in more than one alphabetical directory. Then there are problems of omissions and errors, as well as unlisted numbers, newly listed but unpublished and recently moved subscribers. In the United States it has been shown that there are demographic/psychological differences between those listed and unlisted, and that these differences cause a difference in answers to questions (Brunner \& Brunner, 1971).

Random digit dialing that does not rely upon a telephone directory provides a solution to the problem of unlisted numbers. As all telephone numbers are composed of a combination of ten digit numbers, it is possible to arrive at a sample by using a random number generator to produce a list of numbers. This technique has certain advantages - sample bias is reduced as each subscriber number has an equal chance of selection. The results are more statistically reliable as easier multi-stage and stratification sampling techniques can be used, household respondents can be randomly selected, and callbacks can be based on criteria chosen by the researcher. There are problems, however, in using completely random numbers. There are many more digit numbers possible than residential telephones and thus there will be wasted calls leading to higher interviewer expense. Non-working numbers may be dialed and errors may be made. This leads to increased costs. Glasser \& Metzger (1972) showed that households in the United States with multiple telephone numbers have a higher probability of entering the sample. They suggested correcting the bias by finding out from the respondent the number of telephone numbers and weighing the responses by the universe of this number.

Random digit dialing with the use of alphabetical telephone directories may be appropriate when the geographic area to be sampled matches the area covered by a telephone directory and appears more appropriate in local studies than national studies. An often-used method for random-digit directory sampling is the addition or subtraction of one or more integers (between 0 and 9) to the number selected from the directory. There are problems with random digit numbers created from directory listings. New exchanges are missed and useless calls are made, for example, to telephone booths. A major statistical drawback of the technique is that unless assumptions are made about the distribution of unlisted numbers the sample will not give each household number an equal chance of selection. Bias is introduced insofar as the sample is different from responses of numbers which could be in the 
sample. Landon \& Banks maintain that: 'The magnitude of bias is related to the percentage of telephone households excluded and the degree of difference for the relevant variables between those excluded and those included' (Landon \& Banks, 1977:296). These authors conducted two local telephone studies, 500 telephone numbers were selected by a random digit design and 500 by a plus-one design. They found that the plus-one sample design was more efficient than the random digit design, but potentialiy more biased because all working residential telephone numbers do not have a chance of inclusion. They concluded that researchers should carefully compare the sample's demographic characteristics with the known characteristics of the population as a check on bias. Rich (1977) maintains that in geographic areas where the proportion of unlisted or non-published numbers is high, or where specific demographic attributes are closely related or known to influence results, a procedure such as random digit dialing should be used. He qualifies this by saying that the cost of random digit dialing should be weighed carefully against the value of properly representing non-published numbers in the survey findings.

When deciding whether or not to use random digit dialing, one needs an assessment of the extra interviewer cost. Lyons \& Durant (1980) developed a ratio of random digit dialing to directory-based interviewer costs and determined the interview length at which the disadvantage of extra cost was neutralized. This enabled them to develop a formula for computing extra interviewer costs. They established the viability of random digit dialing for large area surveys and found that while shorter interviews would be marked by a substantial ratio of random digit dialing to directory-based interviewer expense, the actual monetary cost of interviewer time using random digit dialing is constant regardless of interview length.

\section{Questionnaire design}

Once the sampling method has been selected, questionnaire design becomes important.

In developing the questionnaire the telephone interviewer should ask himself certain important questions. Can the questions be understood easily over the phone? Is the respondent able to answer the question? Is it within the respondent's likely experience? Is the question itself pertinent? Does it relate to the study's objectives?

Questions can be grouped into different classes: Open-end, multiple-choice, dichotomous and value-judgement questions. As far as open-end questions are concerned, there is an infinite range of possible replies. Respondents are able to answer questions in their own words and express any further ideas. There are more disadvantages than advantages, however, with these types of questions. There is the problem of tabulating responses, the fact that these questions give more weight to replies from better educated, more literate people. Great interviewer skill is required and there is the possibility of interviewer bias because of the difficulty of recording answers. Multiple-choice questions allow the respondent to choose one or more answers from a number of specific alternatives. They have the advantage of easy questioning and tabulating. However, it has the disadvantage of bias in that respondents will tend not to add an additional reply and therefore an important category may be missed. There may aiso be bias caused by the position of possible answers on questionnaires, although this can be overcome by alternating the order in which the answers are listed in different sets of questionnaires - the 'split-ballot' approach. However, this approach leads to increased costs of production. Another type of bias occurs when respondents have to choose between numbers as they tend to select middle numbers, not extremes. When the letters A, B, C are used, there tends to be a bias towards choosing letter $\mathrm{A}$.

Dichotomous questions are similar to multiple-choice questions, but there are only two choices and a third category 'other' or 'don't know'. These questions have the advantage of easy handling, little interviewer bias and simple computer coding.

Value-judgement questions elicit the respondent's degree of opinion about an issue or an object. The series of answers are either ranked (ordinal scale) or ranked and the distance between ranks made equal (interval scale). There remain many unresolved questions regarding the administration of ranking and rating scales in telephone interviews. It is undecided which type of scale works best. There have been no studies on the ability of respondents to answer questions involving negative scale categories or the number of alternatives respondents can rank in telephone interviews with most questionnaire compilers relying on the number seven plus or minus two.

When formulating questionnaires there are certain general principles that should be borne in mind. It is important to create respondent rapport as soon as possible, therefore attention should be paid to the introduction, which should be simple, and to the opening questions, which should be simple and interesting. Questions should: Be unambiguous, related to specific experiences of the respondent, not use extreme phrasing, be non-emotional and unbiased. The length of the questionnaire should be related to the respondent's interest in the subject matter, and personal questions, for example, about income and age, should not be asked at the outset, only when complete rapport has been established, as should be the case with questions which reflect the respondent's intelligence and questions with little respondent interest. A further factor is that questions should be asked in proper psychological sequence so that they set up a train of thought. When questions are asked over the telephone it is, firstly, important to realize that the first few seconds are crucial because they determine interview continuation and, secondly, that the questionnaire must be conversational. Questions must not be condescending, involved or stilted.

Tyzoon Tyebjee (1979) has discussed computer control of telephone interviewing, one of the newer measures of telecommunication technology advances. The computer can be used to generate random telephone numbers, dial selected numbers, order the questions, transmit them to an interviewer and receive, check, store and analyze the respondent's answers. The computer also provides an editing function, is able to personalize and customize the working of future questions, does not have interview bias as it provides no variation in questionnaire administration and because of its impersonal nature, respondents feel more able to admit to socially undesirable behaviour.

There are other measures such as voice pitch analysis and response latency. Voice pitch analysis has been used to measure the importance of product attributes. Response latency (the time delay before a respondent answers a question) has been used to indicate how well a brandname has been learnt as well as strength of preference for different brands. Various researchers have established that the faster an answer is given, the stronger the respondent's conviction (Barker, 1976). MacLachlan, Czepiel and LaBarbera (1977) showed that response latency data can be gathered efficiently and effectively in telephone interviewing with an automatic voice-operated relay device. From their findings they gathered that response latency 
is a robust measure which is unaffected by the serial position of questions, practice effects, or respondent boredom and that it may be useful for questions which are of low interest to respondents. Because latency sharply differentiates respondents giving correct answers from those giving incorrect answers, there is an inverse relationship between latency and the probability that a question is answered correctly. From the managerial viewpoint, their study showed that response latency data can be gathered in a manner which is cost efficient. Furthermore, the method can be used for both low-involvement and high-involvement questions.

As far as non-contact and refusal rates in consumer telephone surveys are concerned, Wiseman \& McDonald (1979) carried out an industry-wide analysis of non-response in consumer telephone surveys. Their results showed that in many consumer telephone surveys a large percentage of designated respondents or households are not contacted. With regard to those that are contacted, the chance of a refusal is more than one in four. Both uncontrollable and controllable factors affect the level of non-contacts and refusals. A significant factor was that there was a low non-contact rate for surveys in which many attempts were made to contact respondents. In fact, response rates can be improved if certain methodological procedures are used. The resultant increased costs can be counteracted by a reduction in sample size, and in any event the quality of data on which management decisions may be based will be improved.

\section{Protection of privacy and maintenance of confidentiality}

An area of growing importance is the protection of privacy and maintenance of confidentiality. A problem exists in that responding truthfully to particular questions may cause the respondent to feel embarrassed or that his privacy is being invaded. Weber (1976) has found that the asking of personal questions can have a strong effect on completion rates. As far as respondent anonymity is concerned, various techniques have been introduced. For example, Warner (1965) put forward the randomized response technique. This technique is used in the interviewing or data collection stage. The respondent may be given two statements, for example: I am aged over 50 years and I am not aged over 50 years. She is then given a device (e.g. a dice) by which to choose randomly one of the two statements, the interviewer having no knowledge of the outcome and merely recording the respondent's answer. The technique of 'error innoculation' has been used to protect the confidentiality of already collected data. This method maintains confidentiality by, for example, allocating random numbers to individual's names.

\section{The future of professional telephone surveys}

Blankenship (1977) has considered the future of telephone surveys. Some of his conclusions are that there is continuing pressure to increase telephone surveys, there will be technological improvements such as computerized dialing and recording and the videophone, and there is the possibility of government regulation. Government regulation may, for example, prohibit unsolicited telephone calls to people who have indicated that they do not want to receive these calls. While it appears that telephone interviewing is definitely here to stay and that many advances have been made, government regulation may be the obstacle in its path.

\section{References}

Barker, R. September 1946. An experimental study of the relationship between certainty of choice and relative valence of the alternatives. J. Pers., No. 15, $82-94$

Blankenship, A.B. 1977. Professional Telephone Surveys. Ist Edition. New York: McGraw-Hill, 224p.

Brunner, J.A. \& Brunner, G.A. February 1971. Are voluntary unlisted telephone subscribers really different. J. Mark. Res., vol. $8,121-124$

Glasser, G. \& Metzger, G.D. February 1972. Randorn digit dialing as a method of telephone sampling. J. Mark. Res., 59-64.

Kish, L. 1965. Survey Sampling. 1st Edition. New York: John Wiley and Sons, 628p.

Kildegaard, I.C. 1966. Rejoinder. J. Advert. Res., vol. 6, No. 3, $40-41$.

Landon, E.L. \& Banks, S.K. August, 1977. Relative efficiency and bias of plus-one telephone sampling. J. Mark. Res., 296-304

Lyons, W. \& Durant, R.F. Summer 1980. Interviewer costs associated with the use of random digit dialing in large area samples. J. Mark., vol. 44, 65-69.

MacLachlan, J.M., Czepiel, J. \& LaBarbera, P. November 1977. Implementation of response latency measures. J. Mark. Res., vol. 16, $573-577$.

Payne, S.A. 1977. Data collection methods: Telephone surveys. Ist Edition. New York: McGraw-Hill.

Rice, J.M. January 1979. Telephone surveys - a neglected forum of research. Insight, $1-6$.

Rich, C.L. August 1977 . Is random digit dialing really necessary? J. Mark. Res., $300-305$.

Tigett, D.J., Barnes, J.B. \& Bourgeois, J.C. Spring 1975. Research on research: Mail parcel versus telephone survey in retail image analysis. The Canadian Markerer, 22 - 27.

Tyebjee, T.T. Summer 1979. Telephone survey methods: The state of the art. J. Mark., 68-79.

Warner, S.L. March 1965. Randomized response: A survey technique for eliminating evasive answer bias. J. Am. Stat. Assoc., 63-69.

Weber, J.D. 1976. Completion rates in consumer research: Problems and proposed solutions. Bowling Green. Unpublished.

Wiseman, F. \& McDonald, P. November 1979. Noncontact and refusal rates of consumer telephone surveys. J. Mark. Res., vol. $16,478-484$. 